\title{
Development of Sustainable Logistics for Indonesian Remote and Rural Islands Connectivity: A Case Study of the Anambas Islands Regency
}

\author{
Kuncoro Harto Widodo ${ }^{1,3, *}$, Anjar Kistia Purwaditya ${ }^{2}$ and Joewono Soemardjito ${ }^{3}$ \\ ${ }^{1}$ Department of Agro-Industrial Technology, Faculty of Agricultural Technology, Universitas Gadjah Mada, Indonesia \\ ${ }^{2}$ Department of Bio-resources Technology and Veterinary, Vocational School, Universitas Gadjah Mada, Indonesia \\ ${ }^{3}$ Center for Transportation and Logistics Studies, Universitas Gadjah Mada, Indonesia
}

Received: 2020-08-09

Accepted: 2021-04-03

Keywords:

islands connectivity;

logistics;

remote;

rural;

sustainability

Correspondent email: kuncorohw@ugm.ac.id

\begin{abstract}
Usually, countries have a fundamental problem in fulfilling remote and rural island inhabitants' logistical needs. This study was aimed to analyze the performance of logistics systems in Indonesian remote and rural islands by focusing on the Anambas Islands Regency case. We proposed a House of Sustainable Logistics method by considering and combining the framework used in the House of Quality based on the variable of sustainable logistics systems (profit, people, and the planet) with the variables of seven key general logistical drivers (infrastructure, information and communication technology, human resources, logistics service providers, regional laws and regulations, regional institutions, and key commodities.). The study results indicated five key aspects of potential prime movers to be developed (ASLDPj value $=54$ ); they are infrastructure, human resources, logistics service providers, local laws and regulations, and key commodities.
\end{abstract}

\section{Introduction}

The amount of research and publication in the logistics and supply chain management fields is extensive. Although the research is growing in industrial and corporate sectors, it is rare to find literature on regional or area and sustainable logistics management (Widodo, 2010; Widodo et al., 2012; Widodo et al., 2019; Widodo et al., 2020; Wichaisri and Sopadang, 2013). Countries usually have difficulty in fulfilling their remote and rural island inhabitants' logistical needs. Therefore, we need an appropriate and sustainable method to provide logistical or freight connectivity to these areas. In such a situation, the availability of adequate transportation infrastructure networks in remote and rural islands is essential for realizing local connectivity (Putra et al., 2019).

In the context of economic growth, inter-island transport must be affordable, accessible, and reliable. By constructing a port and facilitating goods' movement; transportation infrastructure can foster economic development (Hope, 2008). The port's existence as a part of infrastructure development may affect economic development by decreasing production costs, affecting the industrial location, enhancing regional productivity, and lowering the cost of inter-island trade (Lem, 2002). Further, improving the marine port's capacity to be a hub for carrying local commodities and products will assist local economic development (Nurhayati and Purnomo, 2017). The improved communication, infrastructure, and barrier-free trade will create local capital for the archipelagic region (Putri and Salim, 2020).

As an archipelagic country, sea freight transportation networks have a vital role in an area spanning more than five million square kilometers (Sjafruddin et al., 2010). Interisland domestic transport is crucial to reach outer islands that are spread across vast distances and to service productive sectors such as tourism, fisheries, and agriculture (UNCTAD, 2014). Under these conditions, inter-island connectivity needs to be optimized, especially for islands included in the outer and remote categories.

To optimize connectivity, the government of the Republic of Indonesia established the sea toll program. This program is to realize effective inter-island connectivity with ships scheduled to sail regularly to rural areas of Indonesia to provide an equitable food supply to the outer and remote islands (Presidential Regulation of The Republic Indonesia, 2012). The sea toll program's role is to address the lack of connectivity and create sustainable inter-island freight shipping operations that will attract shippers, traders, and manufacturers to use the services more frequently (Negara and Das, 2017).

Sustainable food supply is vital to meet the community, households, and individuals' food consumption, as mandated by Law Number 18, 2012 concerning food and is an essential aspect in the effort to provide food for the community. Distribution plays a vital role in the process of consistently providing food at all times to meet the community's need for food (He et al., 2018). Sea transportation also contributes and plays a vital role in ensuring the availability of buffer stocks for food supply (Widodo et al., 2013).

The Anambas Islands have an essential role in the national security policy's reform strategy framework to protect Indonesian maritime routes and borders (Suseto et 
al., 2018). However, the Anambas Islands Regency, as one of the outermost and most remote areas in Indonesia, still depends on the supply of food commodities from outside the region (Center for Transportation and Logistics Studies, 2019) (Figure 1). In such situations and conditions, this Regency is highly vulnerable to food availability, especially during high sea tides or during the long dry seasons. The supply and distribution system required serious attention from the central and regional governments to ensure that the local community acquires the supply of commodities or goods needed, especially staple food commodities and essential goods.

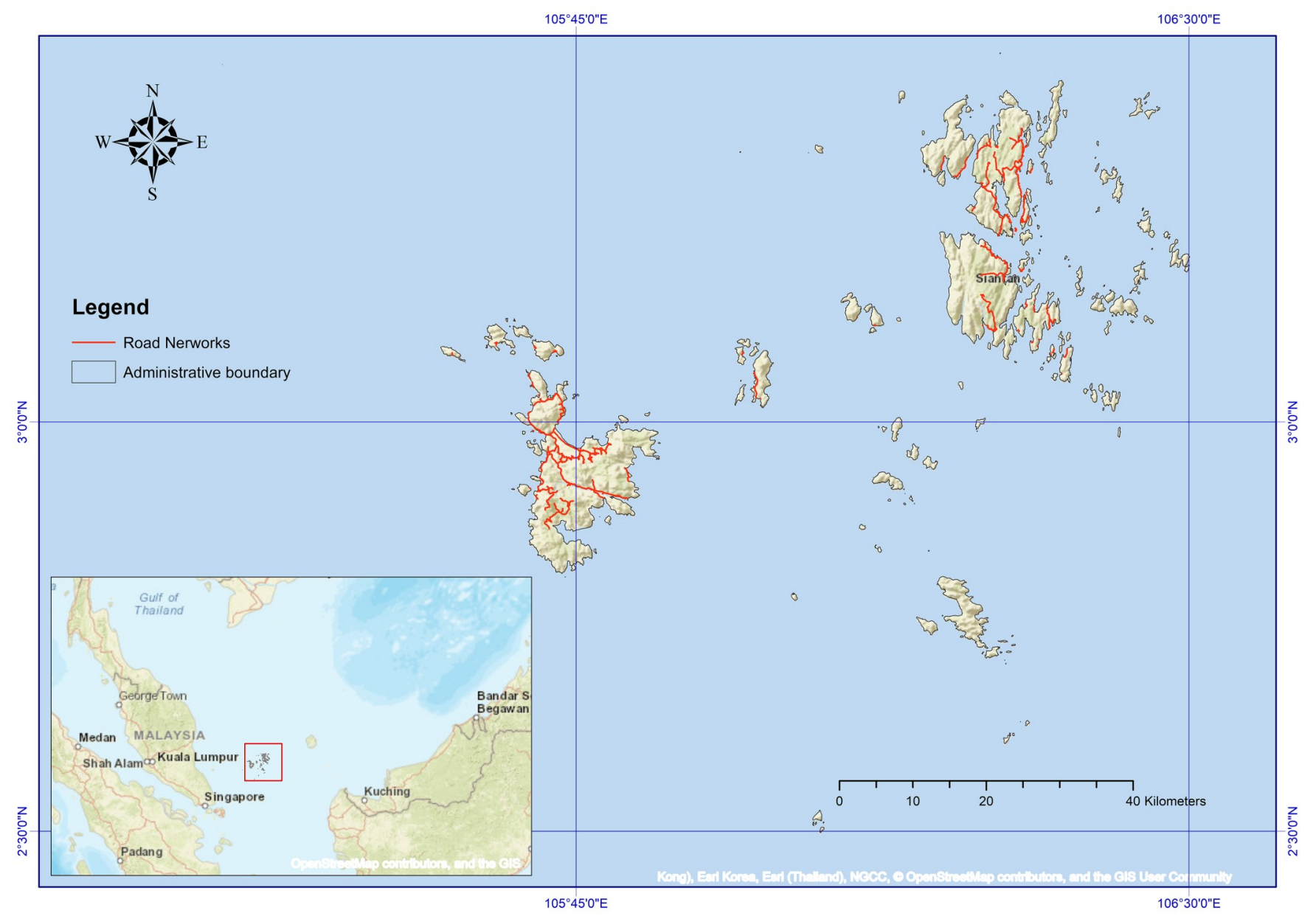

Figure 1. Anambas Islands Regency on the map of Indonesia Source: Indonesian earth map available at https://tanahair.indonesia.go.id/portal-web (processed, 2021)

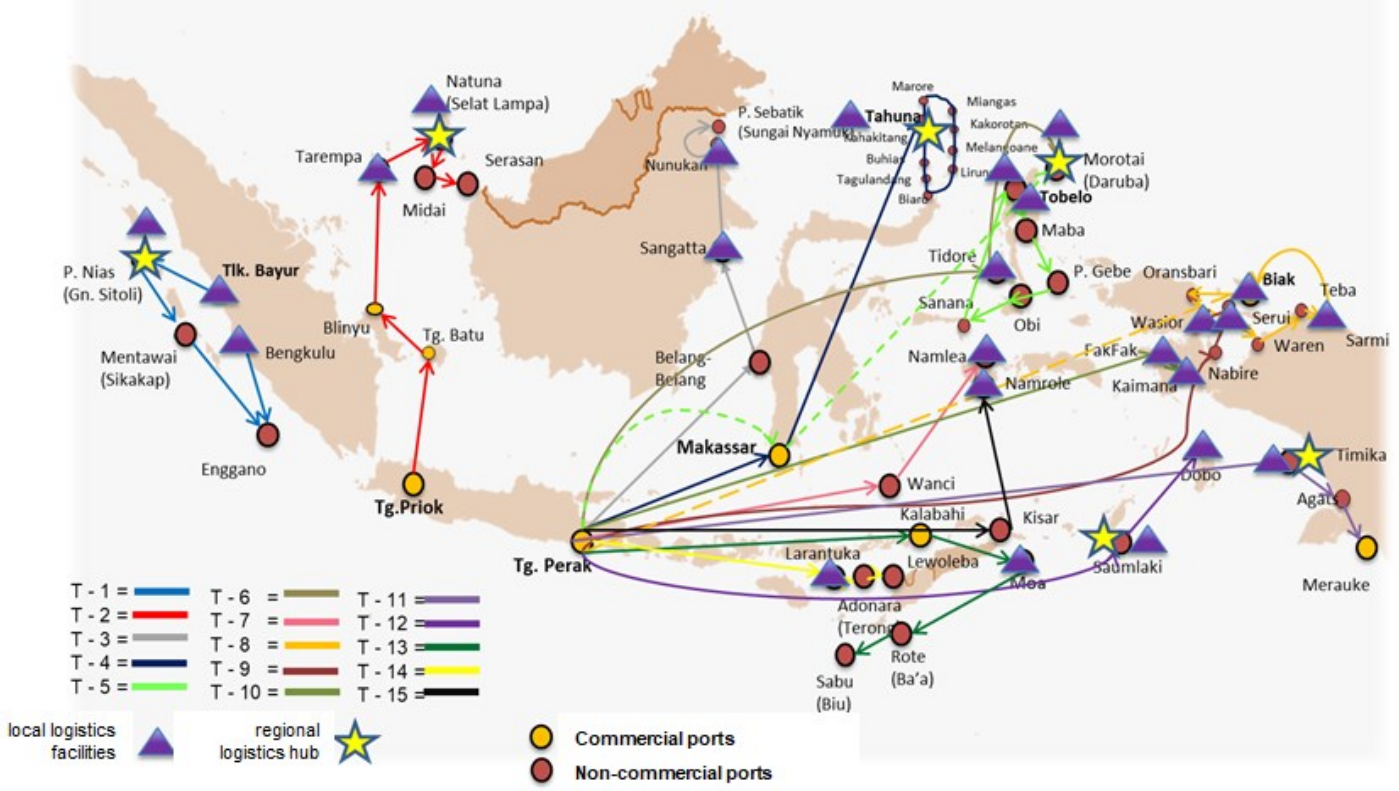

Figure 2. Indonesian sea toll routes

Source: Coordinating Ministry for Maritime and Investment Affairs of the Republic of Indonesia, 2019 
One of the sea toll routes that reach the Anambas Islands Regency is the T-2 sea toll. The T-2 sea toll route is Tanjung Priok - Tanjung Batu - Blinyu - Terempa (Anambas Islands) - Natuna (Lampa Strait) - Midai - Serasan - Tanjung Priok. A ship-subsidy scheme served by the CARAKA JAYA NIAGA III-4 vessel owned by PT PELNI is one of the stateowned enterprises engaged in shipping (Coordinating Ministry for Maritime and Investment Affairs of Republic of Indonesia, 2019). From 2017-2019, the vessels that sailed the sea toll to Anambas Islands Regency carried on average 207 tons of goods per month, whereas the outward-bound goods amounted to only 8.7 tons per month. In other words, the outward-bound commodities brought out using the sea toll vessels was only $4 \%$ of the volume of the inward-bound goods brought into Anambas Islands Regency. This finding reflects the inefficiencies of the Anambas Islands Regency's inbound and outbound commodity logistics system (Figure 3 ). Although the sea toll operation is $8 \%$ more efficient than the existing shipping network (Fahmisari and Parikesit, 2017), it has not been able to reduce the final price of goods at the consumer level in Anambas Islands Regency. The implementation of the sea toll has not been able to increase the local productivity of tradable commodities. It was envisaged that sea toll implementation would reduce the cost of inter-island shipping and, in turn, contribute to economic growth and poverty reduction (Horridge et al., 2016).

According to the World Commission on Environment and Development, sustainable development is defined as development to meet the needs of the present without sacrificing the ability of future generations to meet their needs (Kumar, 2015). More specifically, sustainable development involves coordinating the relationship between environmental and economic issues to obtain sustainable social, economic, and environmental conditions (Beamon, 2014).
To maintain the commodity logistics system's long-term sustainability, both inbound and outbound of Anambas Islands Regency, it is necessary to develop a regional and sustainable logistics system (Center for Transportation and Logistics Studies UGM, 2019). Some critical factors can be used as guidelines for such a system: social, environmental, and economic. $\mathrm{Lu}$ et al. (2016) found that external collaboration has a positive relationship with internal management and positively influences sustainable performance. Another study by Cherrafi et al. (2018) showed that the environment affected logistic chain performance. Among other factors, Morgan et al. (2018) highlighted the commitment of resources as being germane to getting good results. Studies were conducted in Brazil by Martins et al. (2019) by cross-checking company reports with literature. They concluded that five factors could be used to implement sustainable logistics. These five factors are practices related to modal choice, vehicle use and routing, warehouse practices, practices regarding suppliers and purchasing processes, practices related to packaging management, expansive management practices, and social programs. Analyzing the study on sustainable logistics mentioned above, we can verify various factors can be used to measure sustainable logistics. This article presents a framework for assessing a sustainable logistics system. The framework that was developed and proposed for analyzing the sustainable logistics system in this study is the House of Sustainable Logistics (HoSL). HoSL is an analytical framework using a matrix adapted from the House of Quality model (Gentili and Galleto, 2002).

Furthermore, this study used the HoSL model as the research framework that will be applied and implemented in the Anambas Islands Regency case study in the Republic of Indonesia. We used the HoSL model to determine which factors of the seven key drivers logistics system should be given priority to obtain an excellent sustainable logistics performance result.

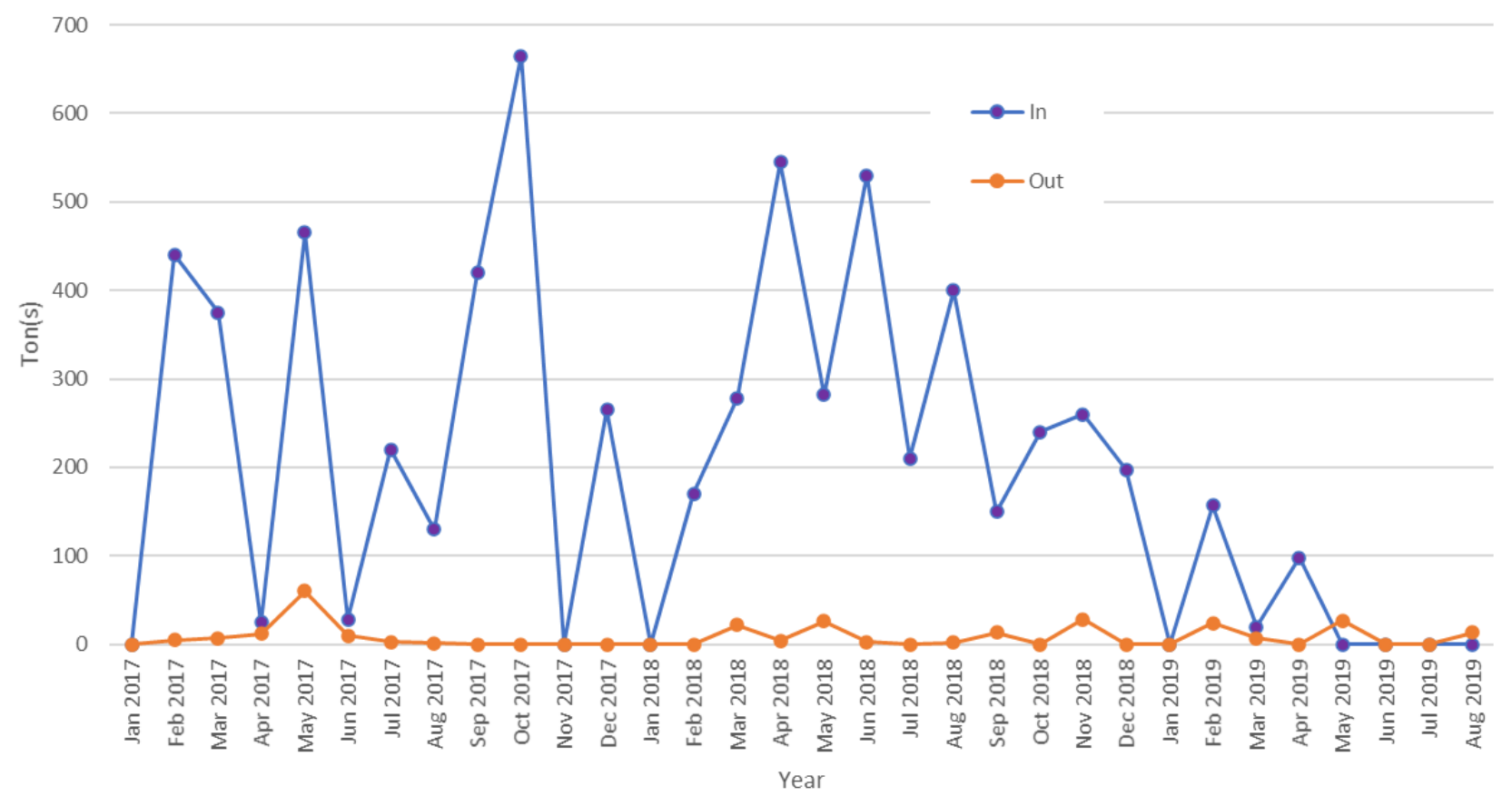

Figure 3. Fluctuations in sea toll vessels' volume into and out of Anambas Islands Regency via Tarempa Port from January 2017 to August 2019

Source: Center for Transportation and Logistics Studies UGM, 2019 


\section{Method}

HoSL model

This study used the HoSL model to analyze the sustainable logistics system in the Anambas Islands Regency case study. This model considered three aspects of sustainable development (profit, planet, and people) and used the seven key drivers for the Indonesian National Logistics System (Presidential Regulation of The Republic Indonesia, 2012). The logistics system's seven key drivers include key commodities, labor, infrastructure, logistics service providers, information and communication technology (ICT), regulations, laws, and institutions. Through the development of a sustainable logistics system, an institution, especially the local government, can take steps to ensure positive performance results in the long term. These positive impacts are related to the program and combine efforts to maximize profits, minimize adverse effects on the environment and improve the community's standard of living (Vidova, Babcanova, Witkowski, and Saniuk, 2012; Min and Kim, 2012).

Each aspect of sustainability will have a different importance rating, and every aspect of sustainable development can be seen in relation to each of the seven key drivers of logistics. Therefore, it is necessary to calculate the aggregate sustainable logistic development potentials $\left(A S L D P_{j}\right) . P_{i}$ is the importance rating of each sustainable development aspect ( $i=$ \{profit, people, planet $\}$ ). $R_{i j}$ is the level of relationship between each aspect of sustainable development with each of the seven key logistics drivers $(j=$ \{key commodities, labor, infrastructure, logistics service providers, ICT, law \& regulation, institution\}). $A S L D P_{j}$ can be calculated using the following equation:

$$
A S L D P_{j}=\sum_{i} P_{i} R_{i j}
$$

Adopting the above procedure, HoSL was developed in the following stages:

1. Identify aspects of sustainable development (SD) for each business process. This identification is conducted by mapping the existing logistics system process. In the HoSL model in Table 1, aspects of SD are placed in the left-hand column.

2. Give an importance rating for every aspect of SD. Scores of importance ratings are 1,2 , and 3 , where 1 represents the lowest aspect of an SD, 2 represents a moderate interest, and 3 shows the highest importance. Each SD aspect's importance value is placed on the right of the SD aspect column in Table 1 and is symbolized as $P_{i}$.

3. Create a correlation matrix to assess $P i$ 's relationship and the seven key logistical drivers $\left(L_{j}\right)$. The relationship between the two components is symbolized as $R_{i j}$ on a scale of 0 (zero), 1 (one), 3 (three), and 9 (nine), with 0 representing no relationship, and 1,3 , and 9 representing a minor relationship, medium relationship, and high relationship, respectively.

4. Calculate the aggregate logistic value of SD $\left(A S L D P_{j}\right)$ with the highest value indicating the highest priority to be developed.

5. Sort the seven key drivers of logistics based on the value from the highest to the lowest $A S L D P_{j}$.

\section{Data collection}

The data used in this study were primary and secondary. The primary data in this study were collected through descriptive quantitative research using the interview method. The method intended to map and identify field data and information and was designed to conform to the research objectives. It was conducted in the location covered by the study. The criteria for respondents were as follows:

1. Respondents must be a logistical policy decision-maker in the Regency, or

2. Respondents must be an expert who was considered to have understood the condition and logistical issues of the Regency.

The secondary data used in this study were data from the Badan Pusat Statistik (BPS) or Statistics' Bureau of Kepulauan Anambas Regency, a regional logistics system study from the Center for Transportation and Logistics Studies, Ministry of Trade, and the coordinating Ministry of Maritime and Investment affairs.

\section{Results and Discussion}

Socio-economic characteristics of the respondents

Most of the respondents who participated in this study were experts in the supply chain and logistics fields and understood the conditions in the Regency of Anambas Islands. The respondents were divided into two clusters, namely, logistical policy decision-makers who understood the situation and logistical issues and who contributed to the supply chain and logistics conditions in the Regency. The respondents who participated in this study consisted of $80 \%$ men and 20\% women. The age of respondents ranged from 31 -57 years, with an average age of 45 years. Most of the respondents' last educational background was masters (60\%), while the rest were respondents who had bachelors (20\%) and doctoral degrees $(20 \%)$.

\section{The current state of the logistics system}

This research was conducted to analyze the logistics system's sustainability in the Anambas Islands' Regency as one of the outermost regions on the Indonesian border and to evaluate its long-term performance. A sustainable logistics system's long-term goal is to achieve a more competitive logistics system, improve quality, and reduce unnecessary activities (Wichaisri and Sopadang, 2013; Kumar, 2015). The performance of any logistics and supply chain is expected to

Table 1. HoSL Model

\begin{tabular}{|c|c|c|c|c|c|c|c|c|}
\hline \multirow[t]{2}{*}{ SD Aspects } & \multirow{2}{*}{$\begin{array}{c}\text { Importance } \\
\text { Ratings } \\
\left(P_{i}\right)\end{array}$} & \multicolumn{7}{|c|}{$\begin{array}{l}\text { Seven Key Drivers Logistics System } \\
\qquad\left(L_{j}\right)\end{array}$} \\
\hline & & $L_{1}$ & $L_{2}$ & $L_{3}$ & $\ldots$ & $\ldots$ & $\ldots$ & $L_{7}$ \\
\hline Profit & $P_{1}$ & $R_{11}$ & $R_{12}$ & $\ldots$ & $\ldots$ & $\ldots$ & $\ldots$ & $R_{17}$ \\
\hline People & $P_{3}$ & $R_{21}$ & $R_{22}$ & $\ldots$ & $\cdots$ & $\cdots$ & $\cdots$ & $R_{27}$ \\
\hline Planet & $P_{2}$ & $R_{31}$ & $R_{32}$ & $\ldots$ & $\ldots$ & $\ldots$ & $\ldots$ & $R_{i j}=R_{23}$ \\
\hline \multicolumn{2}{|r|}{$A S L D P_{j}$} & $A S L D P_{1}$ & $A S L D P_{2}$ & $\mathrm{ASLDP}_{3}$ & $\ldots$ & $\ldots$ & $\ldots$ & $A L S D P_{7}$ \\
\hline
\end{tabular}




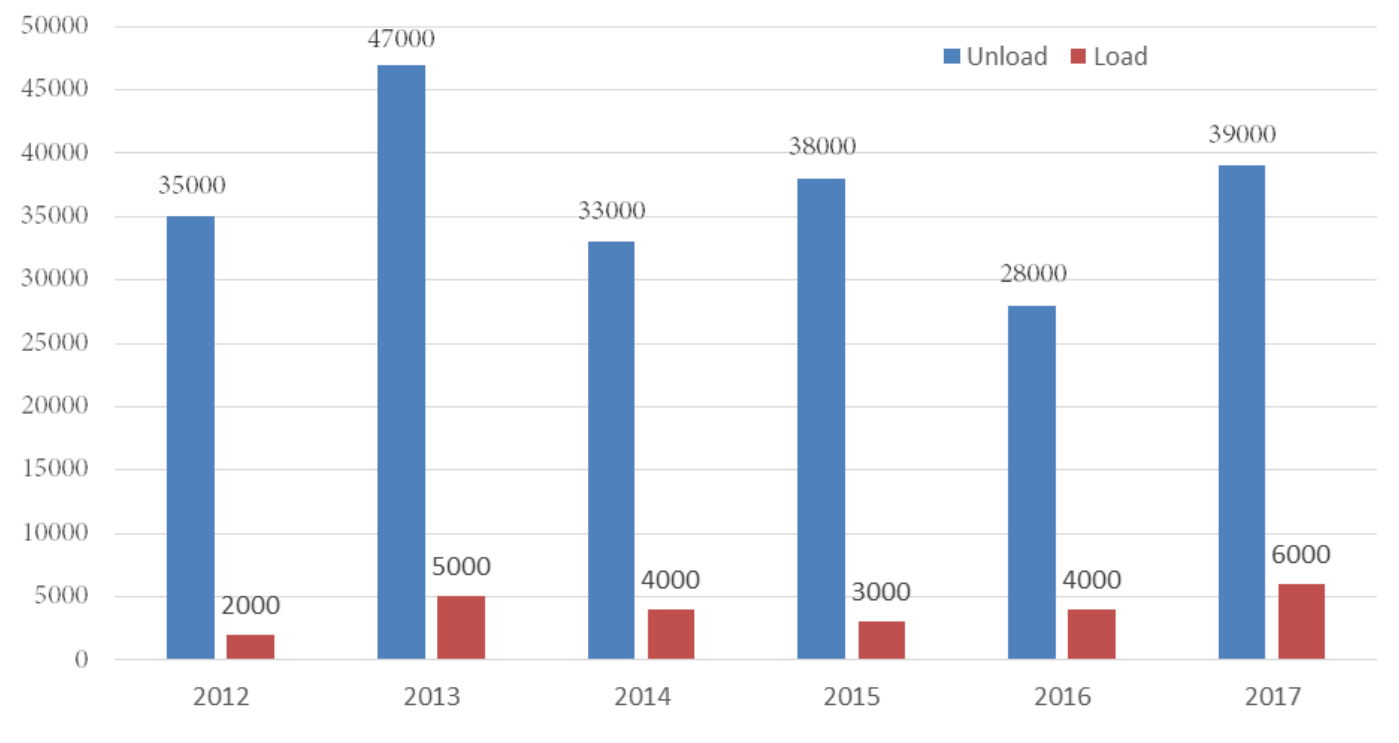

Figure 4. The development of inter-island loading and unloading of goods in the Anambas Islands Regency Source: (Center for Transportation and Logistics Studies UGM, 2019)

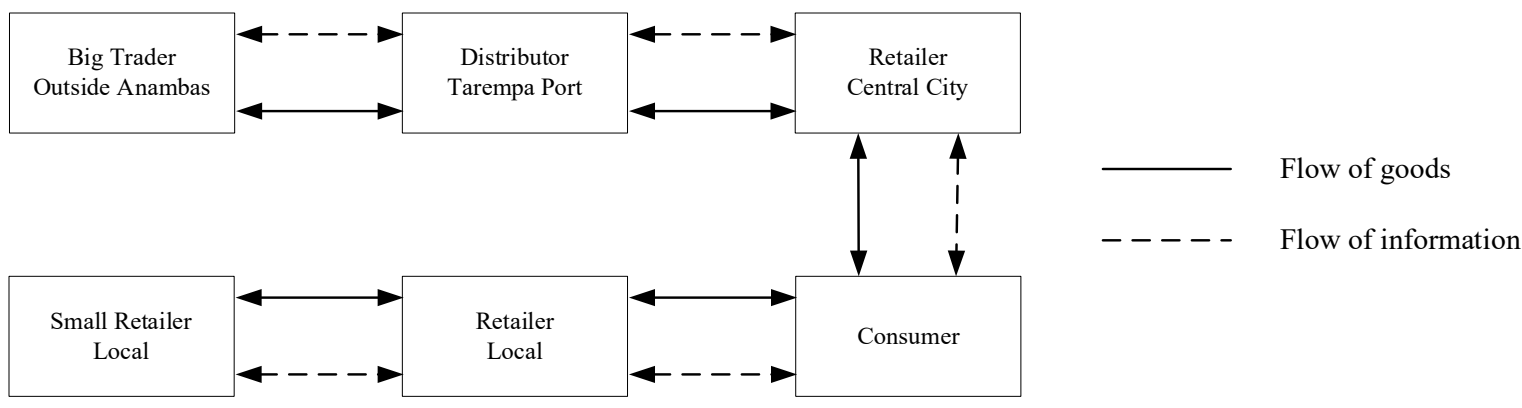

Figure 5. Information and goods flow in the Anambas Islands Regency logistics system

operate in the long-term and be sustainable. We incorporated the above-proposed model to supply chains in Indonesia's outer border regions to evaluate the logistics system.

The potential key commodities from the area are marine and fishery products. The fishery commodity in this Regency has the potential value to be developed as a processed fishery commodity; it has not been optimized yet. It can be seen from the loading and unloading activities which unloading activities are greater than the loading activities of goods in Anambas Islands Regency (Figure 4) (BPS-Statistics' Bureau of Anambas Islands Regency, 2019). The current condition of goods traffic in this Regency's logistics supply chain in this study was found to be dominated more by incoming goods than outgoing goods. The imbalance between incoming goods and outgoing goods will most likely affect the region's planet, profit, and people aspects. In terms of the current situation, policymakers are urged to assess the impact of their strategies and policies on SD.

Under different conditions, another study by Boulanger and Brechet (2005) uses a similar approach to help policymakers assess the impact of their strategies and policies to develop sustainable logistics systems. Using one particular cognitive tool, applied scientific models, they evaluate the system's likely reactions to policy instruments under behavioral and structural constraints with their planet, profit, and people concern.
Importance rating of sustainable logistics criteria

The Anambas Islands Regency's inbound logistics system is described as having a long chain (Figure 5). The logistics experts in the area are concerned about the impact of this long chain on the planet, people, and profit in the Anambas Islands Regency. According to Kumar (2015) study, to make logistics sustainable, we should consider three aspects: profit, people, and the planet. Consequently, if these conditions are not evaluated, then the price of goods at the end consumer level could be very high.

Based on the three aspects of SD, the experts were asked to prioritize the most important ones through questionnaires. These aspects were then assessed using the criteria of 1 (one) to describe the most critical priority and 3 (three) to represent the lowest priority. The results of the expert judgment of the three aspects of SD of the logistics system in the area show that profit is the most crucial aspect, as shown in Table 2.

The profit aspect used to describe sustainability included several factors such as the quality of goods during the distribution process, the speed of fulfilling the needs of the goods, the cost of distributing goods, profits, and the number of goods distributed (Todorovic et al., 2020). The people aspect included workers' health and safety in the logistics system, work environment conditions, and social welfare. The last aspect of sustainability was the planet, including the efficient use of resources (energy, water, raw 
materials, and land use), consideration of the resulting pollution (on water and in the air), and the environmental friendliness of goods (Boulanger and Brechet, 2005; Ahmed et al., 2020).

\section{Aggregate sustainable logistics development potentials}

In support of government policy, aspects of supply chain assessment are based on national logistics system documents that consist of seven key drivers. The seven key drivers of the national logistics system consist of the availability of infrastructure, ICT support, human resources, the existence of logistics service providers, regional law and regulation, regional institutions, and critical commodities in the Anambas Islands Regency (Wichaisri and Sopadang, 2013; Boulanger and Brechet, 2005).

The correlation between the seven key drivers of the logistics system with three aspects of SD was identified using a scale of values of $0,1,3$, or 9 . The aggregate can be calculated from the potential development of a sustainable logistics system by using the two input data on the

Table 2. Importance Rating of Sustainable Development Aspects

\begin{tabular}{lc}
\hline Sustainable Development Aspects & $\begin{array}{c}\text { Importance } \\
\text { Rating }\end{array}$ \\
\hline Entrepreneurs profit (profit) & 1 \\
Community welfare (people) & 3 \\
Attention to environmental impact & 2 \\
(planet) & \\
\hline
\end{tabular}

importance of SD aspects and their correlation with the logistics system's seven key drivers. To illustrate, we use infrastructure aspects, one of the seven key drivers of the logistics system. The infrastructure aspect high correlates highly with three aspects of SD, with each correlation having a value of 9. Therefore, the value of $A S L D P_{j}$ from the aspect of infrastructure is obtained by calculating as follows:

$$
A S L D P_{j}=(1 \times 9)+(3 \times 9)+(2 \times 9)=54
$$

The number 54 is the highest value of $A S L D P_{j}$ with a range of values from $42-54$ (Table 3 ). Based on the data process results, five of the seven key logistics system drivers have the maximum $A S L D P_{j}$ value. The five aspects of the logistics system's seven key drivers are infrastructure, human resources, logistics service providers, local laws and regulations, and essential commodities. The other two aspects, namely, regional institutions and ICT, obtained $A S L D P_{j}$ scores 48 and 42.

By Pareto analysis, the determination of critical sources of risk of immediate mitigation was conducted using the 80/20 concept (Powel and Bonnici, 2014). This concept explained that $20 \%$ of the origins of risk could affect $80 \%$ of the company's business processes. Based on the analysis, five out of seven key logistical prime drivers were prioritized (Figure 6). The five key priority drivers of logistics can be used as a reference to develop a sustainable logistics system in Anambas Islands Regency.

The findings in this article are relevant to the study by Raimbekov et al. (2016) that the critical factors of logistics SD

Table 3. HoSL Model for Anambas Islands' Logistics System

\begin{tabular}{|c|c|c|c|c|c|c|c|c|}
\hline \multirow[t]{2}{*}{ SD Aspects } & \multirow{2}{*}{$\begin{array}{c}\text { Importance } \\
\text { Ratings } \\
\left(P_{i}\right)\end{array}$} & \multicolumn{7}{|c|}{$\begin{array}{l}\text { Seven Key Drivers Logistics System } \\
\qquad\left(L_{j}\right)\end{array}$} \\
\hline & & $L_{1}$ & $L_{2}$ & $L_{3}$ & $L_{4}$ & $L_{5}$ & $L_{6}$ & $L_{7}$ \\
\hline Profit & 1 & 9 & 9 & 9 & 9 & 9 & 3 & 9 \\
\hline People & 3 & 9 & 9 & 9 & 9 & 9 & 9 & 9 \\
\hline Planet & 2 & 9 & 3 & 9 & 9 & 9 & 9 & 9 \\
\hline$A S L D P_{j}$ & & 54 & 42 & 54 & 54 & 54 & 48 & 54 \\
\hline
\end{tabular}

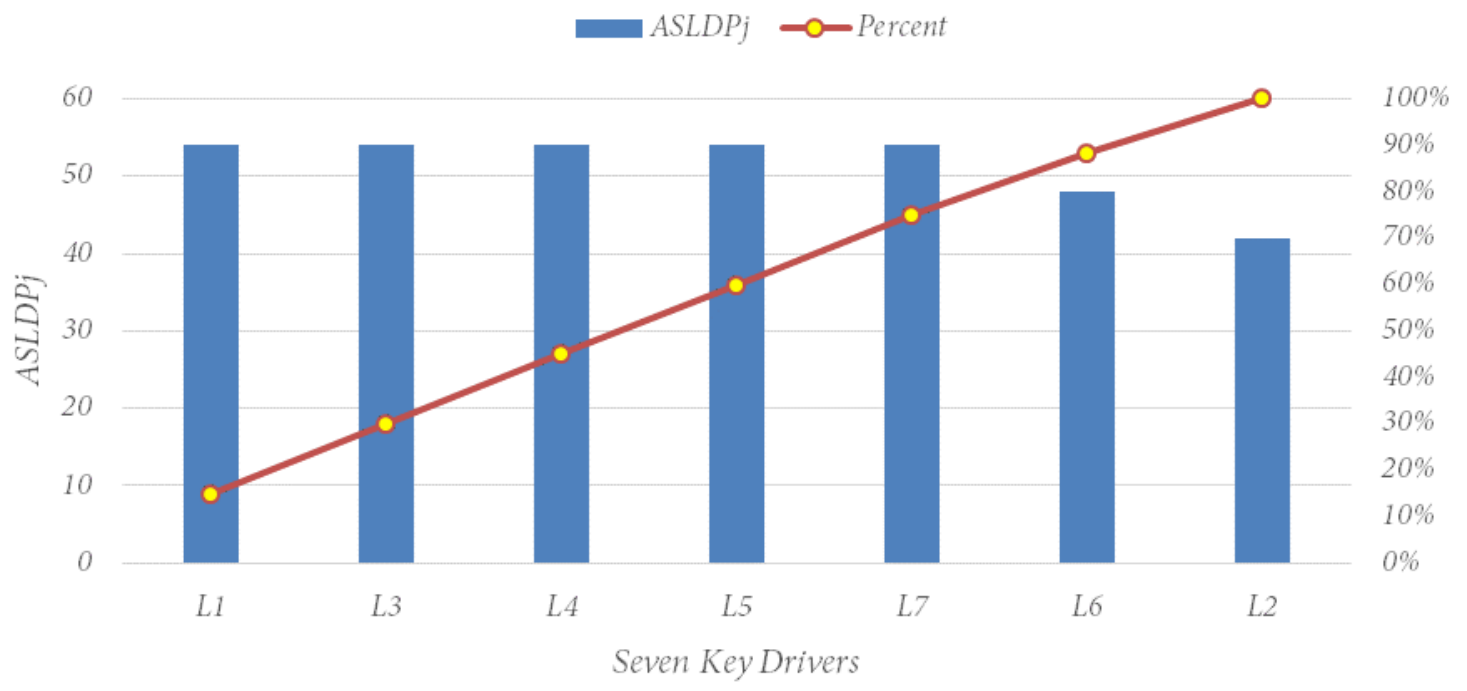

Figure 6. Pareto Diagram of $A S L D P_{j}$ Score of Logistics' seven Key Drivers 
are transport and logistics, investment in the infrastructure, commodity stocks, and increases in transportation tariffs. Good human resources along logistics chains also play an important role in logistics SD, especially in reward management (Kam et al., 2010). The other vital aspects affecting logistics SD are local laws and regulations. For logistics SD, proper legislation and regulations were needed to implement ICT, ITS, and the fourth industrial revolution within cities (Bosona, 2020).

To the best of our knowledge, the HoSL model presented in this paper has never been proposed in any previous literature on logistics SD. As an illustration, the models presented in this study were applied in the Anambas Islands Regency in Indonesia's outer territories. The application of the model is intended to be generic to be used in all cases. It assists in the formulation of policies related to the logistics SD systems. Previous studies in the relevant sector that consider SD would certainly be useful as references in the brainstorming process.

\section{Conclusion}

We proposed a HoSL method to develop freight connectivity for remote and rural islands in Indonesia. By using SD indicators, priorities were decided based on their importance rating to create a logistics SD system in which the sequence was profit, people, and the planet. By implementing and analyzing the HoSL framework in the case of the Anambas Islands Regency of the Republic of Indonesia, we obtained five key aspects of the potential prime movers to be developed with the value of $A S L D P_{j}=54$. The five key aspects that drive the logistics system are infrastructure, human resources, logistics service providers, local laws and regulations, and key commodities.

\section{Acknowledgment}

The authors express deep and sincere gratitude to the Center for Transportation and Logistics Studies (PUSTRAL) UGM and the Local Government of the Anambas Islands Regency of the Republic of Indonesia for providing data and information support for this study. The authors also express deep appreciation to all expert respondents and enumerators for their kind cooperation.

\section{References}

Ahmed, W., Muhammad, A., \& Salman, M. (2020). Importance and Challenges of Green Supply Chain Management in Healthcare. European Journal of Business and Management Research, 290305.

Beamon, B. (2014). Sustainability and the Future of Supply Chain Management. Operations and Supply Chain Management: An International Journal, 4-18.

Bosona, T. (2020). Urban Freight Last Mile Logistics-Challenges and Opportunities to Improve Sustainability: A Literature Review Sustainability 12, no. 21: 8769.

Boulanger, P., \& Brechet, T. (2005). Models for Policy-Making in Sustainable Development: The State of the Art and Perspective for Research. Ecological Economics, 337-350.

BPS-Statistics' Bureau of Anambas Islands Regency. (2019). Anambas Islands Regency in Figures. Anambas Islands Regency, Indonesia: BPS-Statistics' Bureau of Anambas Islands Regency.

Center for Transportation and Logistics Studies UGM. (2019). Study on Local Logistics System (in Bahasa). Yogyakarta, Indonesia: Center for Transportation and Logistics Studies Universitas Gadjah Mada.
Coordinating Ministry for Maritime and Investment Affairs of Republic of Indonesia. (2019). Policy Direction on National Logistics System (in Bahasa). Presentation Material on Focused Group Discussion. Anambas Island Regency. October 11, 2019.

Fahmisari, H., \& Parikesit, D. (2017). Container Shipping Network Efficiency Comparison in Indonesia: Nusantara Pendulum and Sea Tollway. The Asian Journal of Shipping and Logistics. 33(2). 079-084.

Gentili, E., \& Galleto, F. (2002). Quality Function Deployment and Taguchi Methods: A Pragmatical Approach Kulianic E. (eds) AMST"02 Advanced Manufacturing System and Technology. International Center for Mechanical Sciences (Courses and Lectures), 633-640.

He, M., Shen, J., Wu, X., \& Luo, J. (2018). Logistics Space: A Literature Review from the Sustainability Perspective. Sustainability, 2815.

Hope, K. (2008). The Inter-Islands Transport System. Conference Paper on $40^{\text {th }}$ Annual Monetary Studies Conference, 11-14 November 2008. Eastern Caribbean Central Bank, St Kitts and Nevis. 1-29.

Horridge, M., Yusuf, A.A., Ginting, E., \& Aji, P. (2016). Improving Indonesia's Domestic Connectivity: An Inter-regional CGE Analysis. ADB Papers on Indonesia. No. 17. August 2016. Metro Manila, Phillipines. 6.

https://tanahair.indonesia.go.id/portal-web Accessed on February 2, 2021.

Kam, B. H., Tsahuridu, E. E. \& Ding, M. J. (2010). Does Human Resource Management Contribute to the Development of Logistics and Supply Chain Capabilities? An Empirical Study of Logistics Service Providers in China, Research and Practice in Human Resource Management, 18(2), 15-34.

Kumar, A. (2015). Green Logistics for Sustainable Development: An Analytical Review. IOSRD International of Business, 7-13.

Law Number 18 Year 2012 (in Bahasa). (2020, June 19). Retrieved from https://peraturan.bpk.go.id/Home/Details/39100

Lem, L. (2002). Promoting Economic Development by Improving Transport Infrastructure for Goods Movement. US Economic Development Administration.

Min, H., \& Kim, I. (2012). Green Supply Chain Research: Past, Present, and Future. Logistics Research, 39-47.

Negara, SD, \& Das, S.B. (2017). Challenges for Indonesia to Achieve Its Maritime Connectivity Plan and Leverage on Regional Initiatives. Perspective. Singapore: ISEAS Yusof Ishak Institute. 3.

Nurhayati, A. \& Purnomo, A. (2017). Geomaritime-Based Marine and Fishery Economic Development in Maluku Islands. Indonesian Journal of Geography. 49(2). 177-185.

Powel, T., \& Bonnici, T. S. (2014). Pareto Analysis. In C. L. Cooper, Wiley Encyclopedia of Management. Chichester, UK: John Wiley \& Sons.

Presidential Regulation of the Republic Indonesia. (2012). Number 26 Year 2012: Blue Print of Indonesia National Logistic System (in Bahasa). Jakarta, Indonesia: State Secretariat.

Putra, A.A., Magribi, L.O.M., Sukri, A.S., Balaka, R., \& Walendo, L. (2019). Shipping Connectivity in Supporting Logistics Transport Distribution in South East Sulawesi. International Journal of Civil Engineering and Technology. 10(11). 56-65.

Putri, H., \& Salim, W. (2020). The Maritime Silk Road's Potential Effects on Outer Islands Development: The Natuna Islands, Indonesia. Island Studies Journal. 15(2). 155-172

Raimbekov, Z., Syzdykbayeva, B., Baimbetova, A., \& Rakhmetulina, Z. (2016). Evaluating The Impact of Logistics Infrastructure on the Functioning and Development of Regional Economy. Economic Annals-XXI. 160. 100-104.

Sjafruddin, A., Lubis, H.A.S., Frazila, R.B., \& Dharmowijoyo, D.B. (2010). Policy Evaluation of Multimodal Transportation Network: The Case of Inter-islands Freight Transportation in Indonesia. Asian Transport Studies. 1(1). 18-32.

Shrivastava, P. K. (2016). House of Quality: An Effective Approach to Achieve Customer Satisfaction \& Business Growth in 
Industries. International Journal of Science and Research, 13651371.

Suseto, B., Othman, Z., \& Razalli, F.M. (2018). The Need to Reform Indonesia's Maritime Strategy: A Review. Indonesian Journal of Geography. 50(2). 145-153.

Todorovic, V., Maslaric, M., Bojic, S., Jokic, M., Mircetic, D., \& Nikolicic, S. (2020). Solutions for More Sustainable Distribution in the Short Food Supply Chain. Sustainability, 3841.

United Nations Conference on Trade and Development. (2014). Small Islands Developing States: Challenges in Transport and Trade Logistics. Available at https:/unctad.org/system/files/ official-document/cimem7d8_en.pdf. Accessed on February 04, 2021.

Vidova, H., Babcanova, D., Witkowski, K., \& Saniuk, S. (2012). Logistics and Its Environmental Impacts. 7th International Scientific Conference "Business and Management 2012," 10071014.

Wichaisri, S., \& Sopadang, A. (2013). Sustainable Logistics System: A Framework and Case Study. International Conference on Industrial Engineering and Engineering Management (pp. 10171021). Bangkok: IEEE.

Widodo, K. H., Purwaditya, A. K., Sylvia, T., \& Nashih, A. M. (2020). Logistics and Supply Chain System for Fresh Perishable Products (in Bahasa). Yogyakarta, Indonesia: Graha Ilmu.

Widodo, K. H., Parikesit, D., Dewanti, Hadi, M. P., Sa'duddin, Basalim, S., Purwoto, H., Nugroho, D.P. \& Perdana, Y. R. (2019). City Logistics in Indonesia (in Bahasa). Yogyakarta, Indonesia: Gadjah Mada University Press.

Widodo, K.H., Perdana, Perdana, Y.R., \& Riyadi, I.P. (2013). Determination of Sea Transport Route for Staple Food Distribution to Achieve Food Security in the Eastern Indonesia. International Journal of Industrial and Manufacturing Engineering. 7(8). 1683-1690.

Widodo, K. H., Pramudya, K., \& Abdullah, A. (2012). Sustainable Supply Chain Management for Agroindustry (in Bahasa). Bandung, Indonesia: Lubuk Agung.

Widodo, K. H. (2010). Sustainable Supply Chain Based Scenarios for Optimizing Trade-off between Indonesian Furniture and Crude -Palm-Oil Industries. Operations and Supply Chain Management: an International Journah 176-185. 